\title{
Complement Factor H Mutation W1206R Causes Retinal Thrombosis and Ischemic Retinopathy in Mice
}

Delu Song, ${ }^{*}$ Yoshiyasu Ueda, ${ }^{\dagger}$ Rupak Bhuyan, ${ }^{*}$ Imran Mohammed, ${ }^{\dagger}$ Takashi Miwa, ${ }^{\dagger}$ Damodar Gullipali, ${ }^{\dagger}$ Hangsoo Kim, ${ }^{\dagger}$ Lin Zhou, ${ }^{\dagger}$ Ying Song, * Hannah Schultz, * Albert Bargoud, * Joshua L. Dunaief, * and Wen-Chao Song ${ }^{\dagger}$

From the Department of Ophthalmology, ${ }^{*}$ Scheie Eye Institute, and the Department of Systems Pharmacology and Translational Therapeutics, ${ }^{\dagger}$ Perelman School of Medicine, University of Pennsylvania, Philadelphia, Pennsylvania

Accepted for publication January 2, 2019.

Address correspondence to Joshua L. Dunaief, M.D., Ph.D., Scheie Eye Institute, University of Pennsylvania, 305 Stellar Chance Labs, 422 Curie Blvd., Philadelphia, PA 19104; or Wen-Chao Song, Ph.D., 421 Curie Blvd., Room 1254 BRBII/III, Philadelphia, PA 19104. E-mail: jdunaief@ pennmedicine.upenn.edu or songwe@pennmedicine.upenn. edu.

\begin{abstract}
Single-nucleotide polymorphisms and rare mutations in factor $\mathrm{H}$ (FH; official name, $\mathrm{CFH}$ ) are associated with age-related macular degeneration and atypical hemolytic uremic syndrome, a form of thrombotic microangiopathy. Mice with the FH W1206R mutation $\left(\mathrm{FH}^{\mathrm{R} / \mathrm{R}}\right)$ share features with human atypical hemolytic uremic syndrome. Herein, we report that $\mathrm{FH}^{\mathrm{R} / \mathrm{R}}$ mice exhibited retinal vascular occlusion and ischemia. Retinal fluorescein angiography demonstrated delayed perfusion and vascular leakage in $\mathrm{FH}^{\mathrm{R} / \mathrm{R}}$ mice. Optical coherence tomography imaging of $\mathrm{FH}^{\mathrm{R} / \mathrm{R}}$ mice showed retinal degeneration, edema, and detachment. Histologic analysis of $\mathrm{FH}^{\mathrm{R} / \mathrm{R}}$ mice revealed retinal thinning, vessel occlusion, as well as degeneration of photoreceptors and retinal pigment epithelium. Immunofluorescence showed albumin leakage from blood vessels into the neural retina, and electron microscopy demonstrated vascular endothelial cell irregularity with narrowing of retinal and choroidal vessels. Knockout of $C 6$, a component of the membrane attack complex, prevented the aforementioned retinal phenotype in $\mathrm{FH}^{\mathrm{R} / \mathrm{R}}$ mice, consistent with membrane attack complex-mediated pathogenesis. Pharmacologic blockade of $\mathrm{C} 5$ also rescued retinas of $\mathrm{FH} \mathrm{R}^{\mathrm{R} / \mathrm{R}}$ mice. This $\mathrm{FH}^{\mathrm{R} / \mathrm{R}}$ mouse strain represents a model for retinal vascular occlusive disorders and ischemic retinopathy. The results suggest complement dysregulation can contribute to retinal vascular occlusion and that an anti-C5 antibody might be helpful for C5-mediated thrombotic retinal diseases. (Am J Pathol 2019, 189: 826-838; https://doi.org/10.1016/j.ajpath.2019.01.009)
\end{abstract}

Retinal vascular occlusive disorders collectively constitute the most common causes of visual disability in the middleaged and elderly population. ${ }^{1}$ Activation of the complement cascade, a component of the innate immune system, can promote retinal vascular occlusion, as seen in some patients with atypical hemolytic uremic syndrome (aHUS). ${ }^{2-4}$

Complement is activated via three pathways: classic, lectin, and alternative pathways. Factor $\mathrm{H}(\mathrm{FH})$ regulates the alternative pathway by inhibiting the activity of $\mathrm{C} 3$ convertase, $\mathrm{C} 3 \mathrm{bBb}$, both on the cell surface and in the fluid phase. $^{5-7} \mathrm{FH}$ contains 20 short consensus repeat domains; rare mutations in short consensus repeats 19 and 20 of human $\mathrm{FH}$ are associated with $\mathrm{AHUS}^{8-10}$ and age-related macular degeneration. ${ }^{11,12}$ The $\mathrm{C} 3$ convertase activates the C5 convertase, which cleaves C5 into anaphylatoxin C5a and $\mathrm{C} 5 \mathrm{~b}$. The latter promotes formation of the membrane attack complex (MAC), which contains C5b, C6, C7, C8, and C9. The MAC can cause lysis of microbes and human red blood cells as well as activation and injury of nucleated eukaryotic cells by generating holes in the cell membrane.

We previously generated a W1206R mutation in the mouse FH gene corresponding to the W1183R mutation in human FH found in familial aHUS. ${ }^{8-10}$ These mice developed thrombosis in multiple organs, including, as shown in vivo by fluorescein angiography (FA), the retinal vasculature. ${ }^{13}$ Herein, we tested the hypothesis that MAC formation is necessary for the thrombosis by determining whether $\mathrm{FH}$ W1206R mutation $\left(\mathrm{FH}^{\mathrm{R} / \mathrm{R}}\right) / \mathrm{C} 6$ doubleknockout mice are protected from the thrombotic

Supported by NIH grants RO1EY023709, RO1AI085596, RO1AI117410, and EY023709; a BrightFocus Foundation grant M2011051 (W.-C.S.); Research to Prevent Blindness; the F. M. Kirby Foundation; the Paul and Evanina Bell Mackall Foundation Trust; a gift in memory of Dr. Lee F. Mauger (J.L.D.); and the National Center for Advancing Translational Sciences of the NIH grant KL2TR001879 (D.S.)

Disclosures: None declared. 
phenotype of the eye. Detailed in vivo and histologic characterization of the retinal phenotype was studied. The results showed that $\mathrm{FH}^{\mathrm{R} / \mathrm{R}}$ mice developed retinal vessel occlusion, delayed and insufficient retinal perfusion, retinal detachment, inner retinal thinning, retinal pigment epithelium (RPE) degeneration, and basal RPE complement deposits. Knocking out C6, but not the receptor for anaphylatoxin C5a [C5a receptor $1(\mathrm{C} 5 \mathrm{aR})$ ] rescued the retinal phenotype of $\mathrm{FH}^{\mathrm{R} / \mathrm{R}}$ mice, suggesting that the MAC is involved in the pathogenesis. Anti-C5 antibody treatment also protected $\mathrm{FH}^{\mathrm{R} / \mathrm{R}}$ mice from developing the observed retinal phenotype. These findings suggest a causal relationship between FH dysfunction-induced MAC activation and retinal vascular thrombosis.

\section{Materials and Methods}

Animals

The generation of $\mathrm{FH}^{\mathrm{R} / \mathrm{R}}$ mice on a $\mathrm{C} 57 \mathrm{BL} / 6$ background was described previously. ${ }^{13} \mathrm{C}^{-1-}$ mice on a $\mathrm{C} 57 \mathrm{BL} / 6$ background were generated in house from $C 6$ gene-targeted embryonic stem cells obtained from VELOCIGENE
(VG16017; Tarrytown, NY). ${ }^{14} \mathrm{FH}^{\mathrm{R} / \mathrm{R}}$ mice were crossed to $C 5 a R 1^{-1-15}$ and $\mathrm{Cb}^{-1-}$ mice to generate $\mathrm{FH}^{\mathrm{R} / \mathrm{R}} / \mathrm{C} 5 a R 1^{-1-}$ and $\mathrm{FH}^{\mathrm{R} / \mathrm{R}} / C 6^{-1-}$ mice. All animals were screened for the $R d 8$ mutation, and results were negative. Age-matched littermates were used as controls, and both sexes were studied. Numbers of mice used in each experiment are shown in the corresponding figure legends. Experimental procedures were performed in accordance with the Association for Research in Vision and Ophthalmology statement for the use of animals in ophthalmology and vision research. All protocols were approved by the animal care review board of the University of Pennsylvania (Philadelphia, PA).

\section{Fundus Imaging and Fluorescence Angiography}

After anesthesia with a mixture of (in $\mathrm{mg} / \mathrm{kg}$ body weight) 100 ketamine, 2 xylazine, and 2 acepromazine, bright-field imaging of the fundus was performed using a Micron III intraocular imager (Phoenix Research Labs, Pleasanton, CA). After fundus images were acquired, $100 \mu \mathrm{L}$ fluorescein sodium $(0.5 \mathrm{mg} / \mathrm{L}$, AK-Fluor; Akorn Inc., Lake Forest, IL) was injected intraperitoneally, and a fluorescence image was captured immediately at 30 -second intervals.
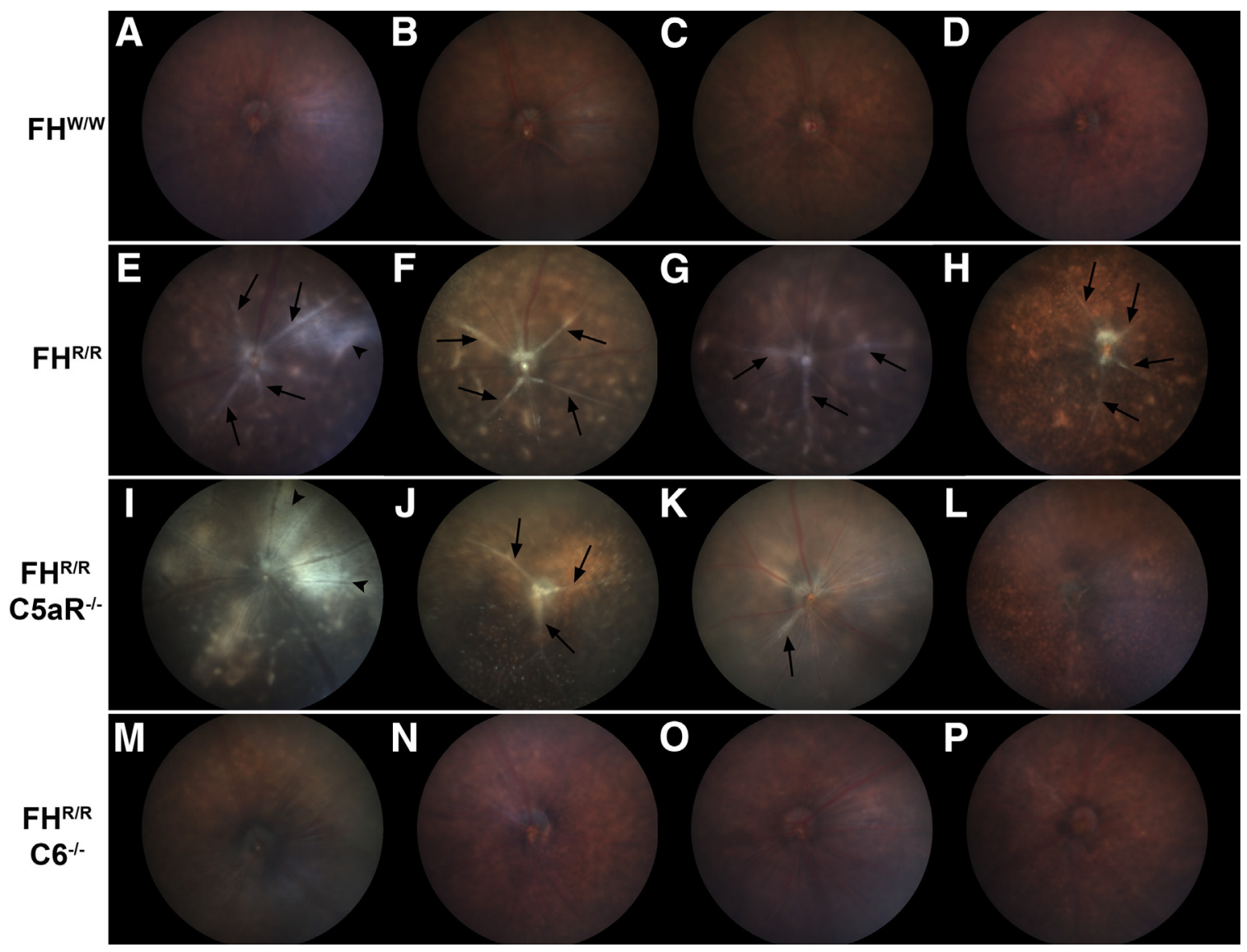

Figure 1 Fundus images taken at 8 weeks of age. A-D: Representative normal fundus images of FH ${ }^{W / W}$ mice. $\mathbf{E}-\mathbf{H}$ : $F H^{R / R}$ mice show occluded vessels (arrows), white ischemic patches (arrowhead), and white spots. I-L: Similarly, $\mathrm{FH}^{\mathrm{R} / \mathrm{R}} / \mathrm{C} 5 \mathrm{aR} 1^{-/-}$mice show occluded vessels (arrows), ischemic patches (arrowheads), and white spots. $\mathrm{M}-\mathrm{P}$ : However, $\mathrm{FH}^{\mathrm{R} / \mathrm{R}} / \mathrm{C \sigma}^{-/-}$mice have normal fundus images. See Figure $2 \mathrm{~B}$ for quantification. 


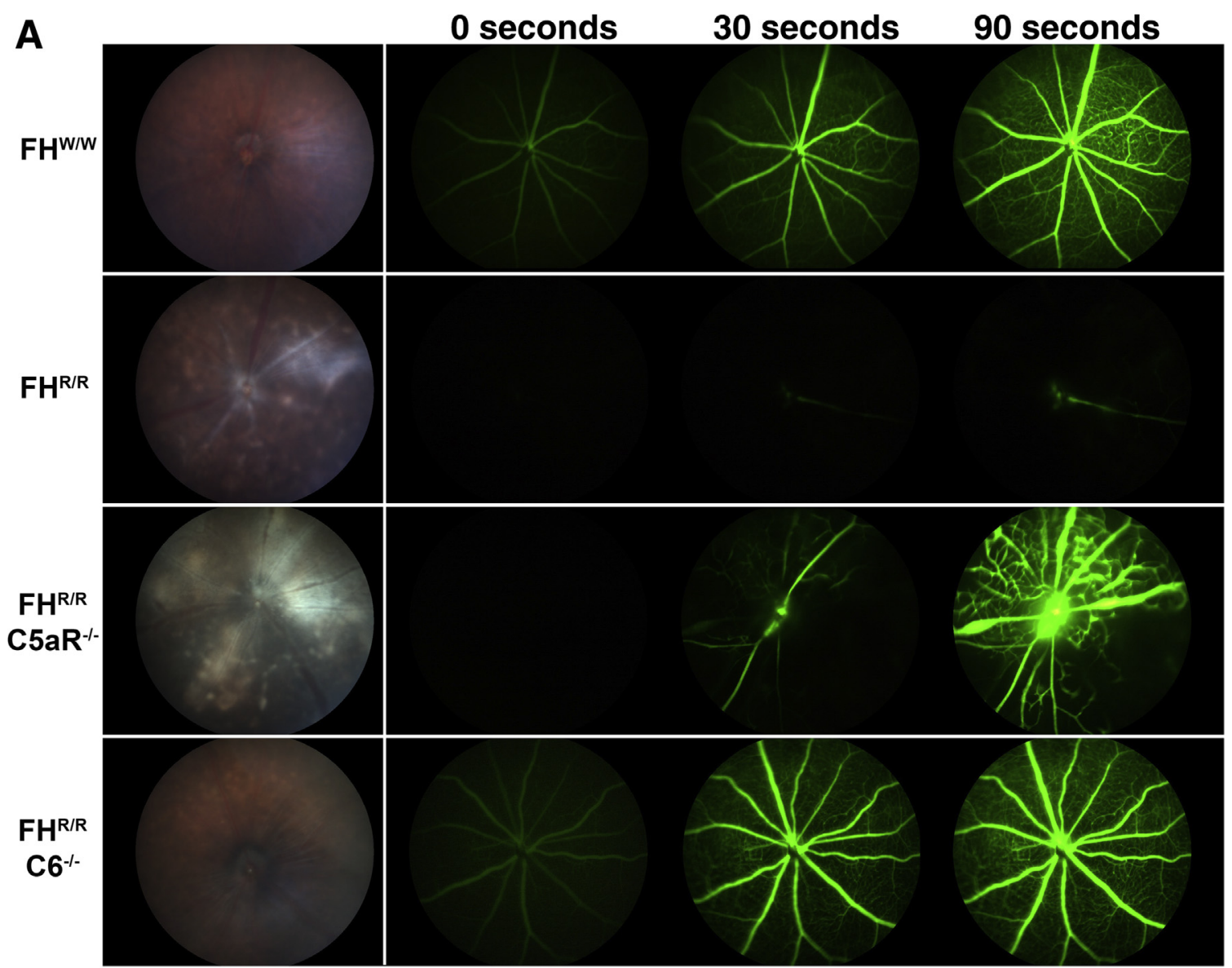

B
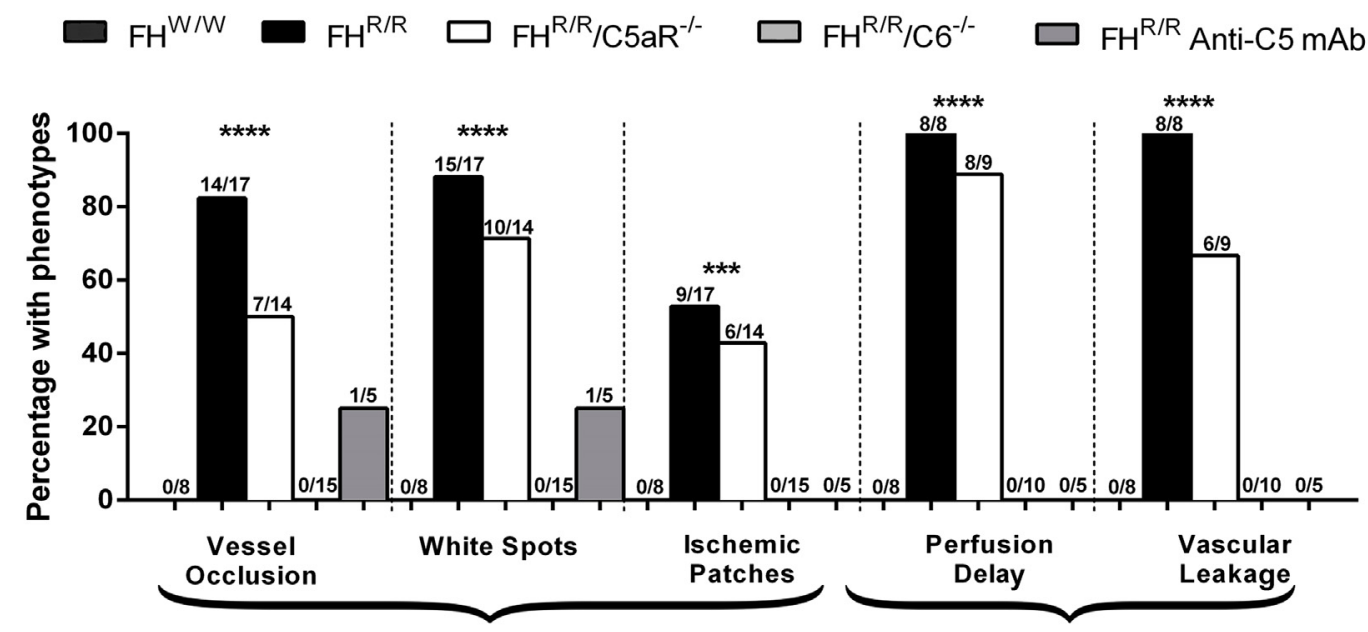

Fundus Images

Fluorescein Angiography

Figure 2 A: Representative fundus images with fluorescein angiography (FA) at the indicated time points. Both $\mathrm{FH}^{\mathrm{W} / \mathrm{W}}$ and $\mathrm{FH}^{\mathrm{R} / \mathrm{R}} / \mathrm{C}^{-/-}$mice show normal fundus and FA images. An $\mathrm{FH}^{\mathrm{R} / \mathrm{R}}$ mouse had almost no perfusion up until 90 seconds, whereas an $\mathrm{FH}^{\mathrm{R} / \mathrm{R}} / \mathrm{CFaR1}^{-/-}$mouse had delayed and incomplete retinal perfusion and fluorescence leakage around the optic nerve head. B: Quantification of abnormalities on fundus images and FA images. Abnormalities, including vessel occlusion, white spots, ischemic patches on fundus images, and perfusion delay and vascular leakage on $F A$ images, are observed in $\mathrm{FH}^{\mathrm{R} / \mathrm{R}}$ and $\mathrm{FH}{ }^{\mathrm{R} / \mathrm{R}}$ / $\mathrm{C5aR1}^{-1-}$ mice, but not in $\mathrm{FH} / \mathrm{W} / \mathrm{W}$ and $\mathrm{FH}^{\mathrm{R} / \mathrm{R}} / \mathrm{CG}^{-/-}$mice. Only one anti-C5 monoclonal antibody (mAb) - treated $\mathrm{FH}^{\mathrm{R} / \mathrm{R}}$ mouse shows vessel occlusion and white spots; the others exhibit no pathologic changes. Fractions represent ratios of abnormal mice/all experimental mice for each genotype. Fisher exact test reveals a significant association between genotype and likelihood of exhibiting all of the observed pathologic changes. Dotted lines separate different graphs. Bars within each graph are displayed in the same order as genotypes in the key. $n=17 \mathrm{FH}^{\mathrm{R} / \mathrm{R}}$ mice $(\mathbf{B}) ; n=14 \mathrm{FH}^{\mathrm{R} / \mathrm{R}} / \mathrm{C5aR} 1^{-1-}$ mice $(\mathbf{B}) ; n=8 \mathrm{FH} / \mathrm{W}$ mice $(\mathbf{B}) ; n$ $=15 \mathrm{FH}^{\mathrm{R} / \mathrm{R}} / \mathrm{C}^{-/-}$mice (B); $n=5$ anti-C5 mAb-treated $\mathrm{FH}^{\mathrm{R} / \mathrm{R}}$ mouse $(\mathbf{B}) .{ }^{* * *} P<0.001,{ }^{* * * * P}<0.0001$. 


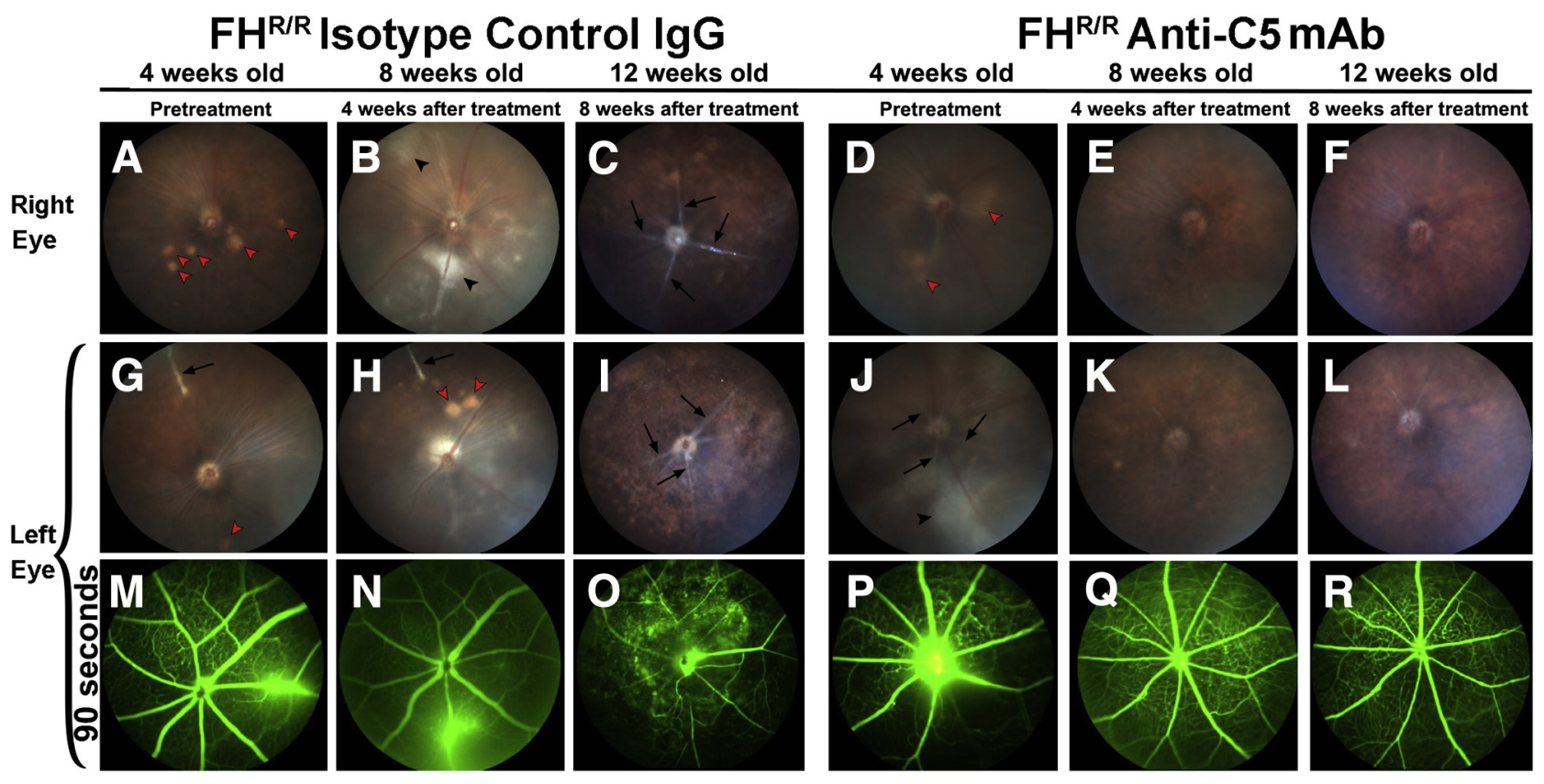

Figure 3 Serial fundus images and fluorescein angiograms (FAs) with increasing age from representative mice before and after anti-C5 monoclonal antibody (mAb) treatment. A-C, G-I, and $\mathbf{M}-\mathbf{0}$ : In a control antibody-treated mouse, white spots are found in both eyes (red arrowheads), with vascular leakage in the left eye (M and $\mathbf{N})$. B, $\mathbf{H}$, and $\mathbf{N}$ : After 4 weeks of treatment with control antibody, ischemic patches (black arrowheads in B) develop in the right eye and hypopigmented spots (red arrowheads in $\mathbf{H}$ ) and vessel occlusion (arrow in $\mathbf{H}$ ) are found in the left eye. After 8 weeks of treatment with control antibody, additional white spots and vessel occlusion (arrows in $\mathbf{C}$ and $\mathbf{I}$ ) are seen in both eyes, with corresponding hypoperfusion on FA (0). Before anti-C5 $\mathrm{mAb}$ treatment (D and $\mathbf{J}$ ), white spots (red arrowheads in $\mathbf{D}$ ), ischemic patches (black arrowhead in $\mathbf{J}$ ), and vessel occlusion (arrows in $\mathbf{J}$ ) are observed, which then disappears after 4 weeks ( $\mathbf{E}$ and $\mathbf{K}$ ) and 8 weeks $(\mathbf{F}$ and $\mathbf{L})$ of anti-C5 treatment. Insufficient retinal perfusion and leakage around the optic nerve head before treatment $(\mathbf{P})$ improves after treatment with anti-C5 $(\mathbf{Q}$ and $\mathbf{R})$.

\section{Morphologic Analysis}

Enucleated eyes were immersion fixed in $2 \%$ paraformaldehyde $/ 2 \%$ glutaraldehyde overnight. Then, eyecups were made by removing the cornea and lens before dehydration in increasing concentrations of ethanol, infiltrating overnight, and embedding the next day in plastic (JB4; Polysciences, Inc., Warrington, PA). For standard histology, plastic sections

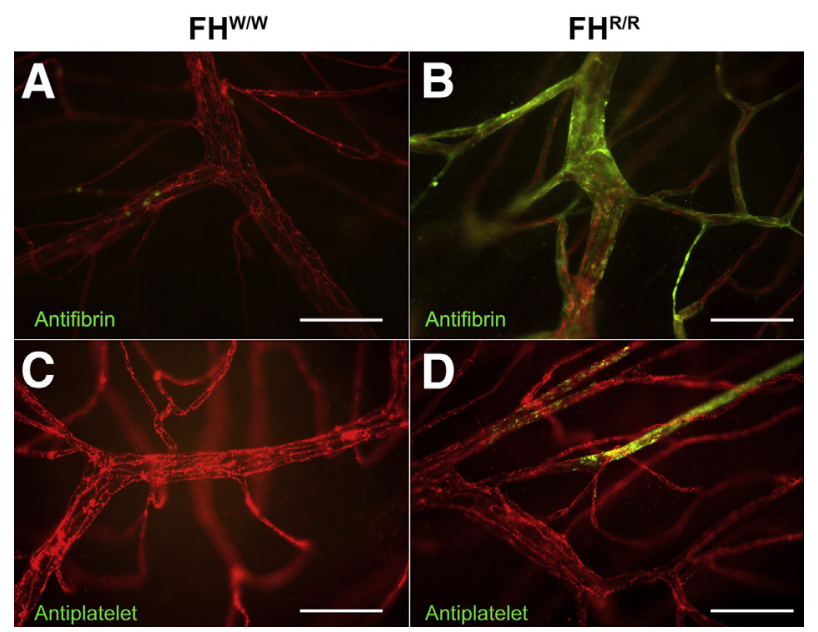

Figure 4 A and C: Minimal labeling is seen in $\mathrm{FH}^{\mathrm{W} / \mathrm{W}}$ mice. $\mathbf{B}$ and $\mathbf{D}$ : Fluorescence photomicrographs of retinal flat mounts showing fibrin (green; $\mathbf{B}$ ) and platelet (green; D) staining in the retinal vasculature of $\mathrm{FH}^{\mathrm{R} / \mathrm{R}}$ mice. Vascular endothelial cells were labeled with anti-CD31 (red). Scale bars $=50 \mu \mathrm{m}$ (A-D).
( $3 \mu \mathrm{m}$ thick) were cut in the sagittal plane and stained with $1 \%$ toluidine blude $\mathrm{O}$ and $1 \%$ sodium tetraborate decahydrate (Sigma-Aldrich, St. Louis, MO) for 5 seconds. Stained sections were then dried and imaged using bright-field microscopy (TE300; Nikon, Tokyo, Japan).

\section{Immunofluorescence}

After the globes were fixed in $4 \%$ paraformaldehyde, eyecups were generated by removing the anterior segment. The eyecups were infiltrated in 30\% sucrose overnight and embedded in Tissue-Tek O.C.T. compound (Sakura Finetek, Torrance, CA). Immunofluorescence was performed on frozen sections $(10 \mu \mathrm{m}$ thick $)$ with fluorescein isothiocyanate-conjugated C3 antibody (number 0855500; MP Biomedicals, Solon, OH), albumin (A90-134A; Bethyl, Montgomery, TX), and CD31 (ab76533; Abcam, Cambridge, MA). Control sections were treated identically with isotype-matched antibodies (ab37374; Abcam).

For immunolabeling of flat mounts, after enucleation, eyes were immersion fixed in 4\% paraformaldehyde on ice for 20 minutes. Eyecups were then generated by circumferential incision at the pars plana, removing the cornea, iris, ciliary body, and lens. After blocking in 10\% normal donkey serum in tris-buffered saline (TBS) plus $0.1 \%$ Triton X-100 (TBST), eyecups were incubated in $100 \mu \mathrm{L}$ of primary antibody in $2 \%$ normal donkey serum in TBST at $4^{\circ} \mathrm{C}$ overnight. Eyecups 


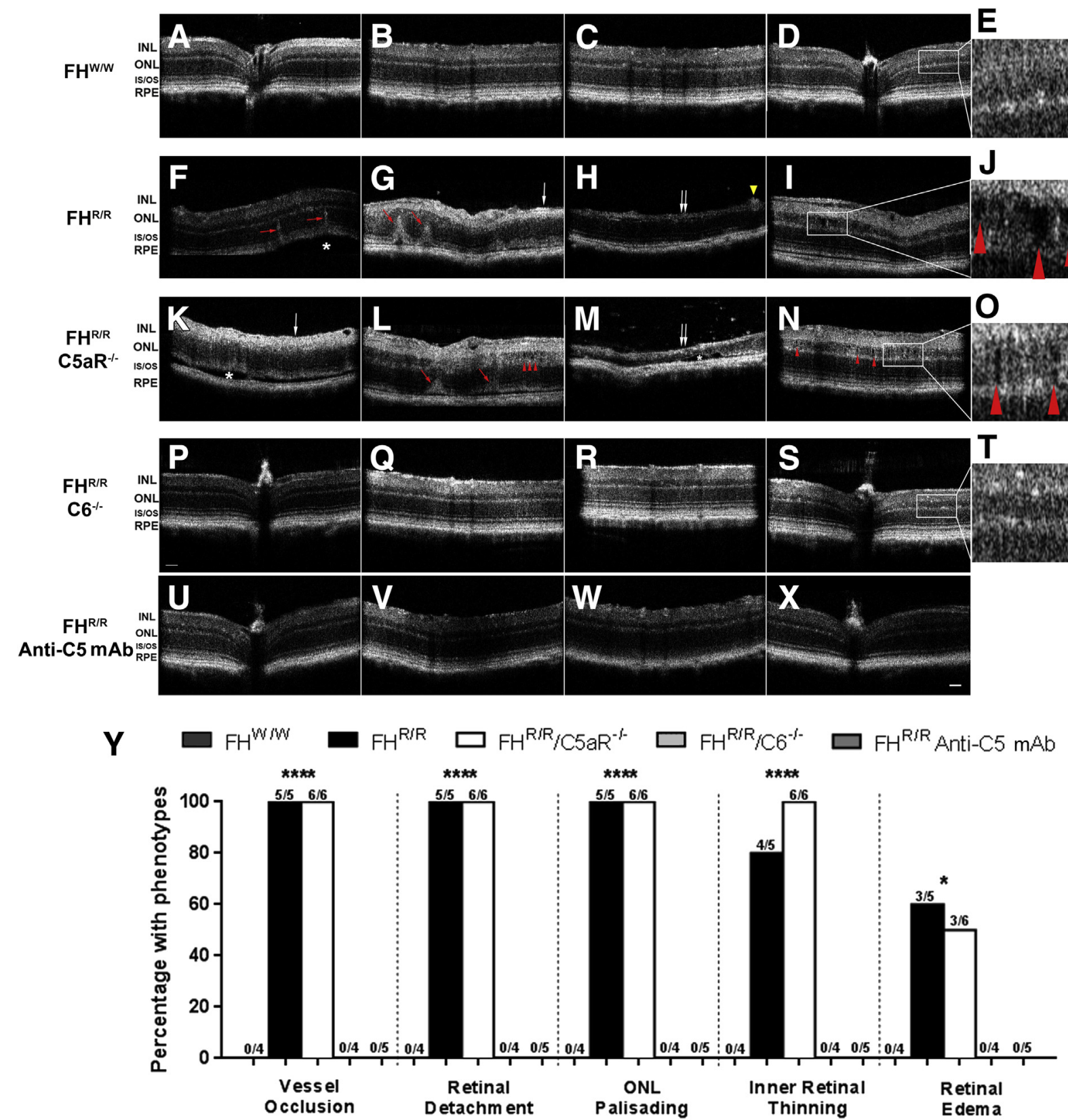

Figure 5 A: Optical coherence tomographic (OCT) images of retinas. A-E: Normal retinas of $\mathrm{FH}^{\mathrm{W} / \mathrm{W}}$ mice. $\mathbf{F}-\mathbf{0}$ : In $\mathrm{FH}^{\mathrm{R} / \mathrm{R}}(\mathbf{F}-\mathbf{J})$ and $\mathrm{FH}^{\mathrm{R} / \mathrm{R}} / \mathrm{C5} 5 \mathrm{R} 1^{-/-}(\mathbf{K}-\mathbf{0})$ mice, retinal detachment (white asterisks), outer nuclear layer (ONL) palisading in regions of disrupted photoreceptor inner/outer segment (IS/OS; red arrows), occluded vessels (yellow arrowhead), inner retinal thinning (single white arrows), total retinal thinning (double white arrows), and retinal edema (red arrowheads) are found. $\mathbf{P}-\mathbf{T}: \mathrm{FH}^{\mathrm{R} / \mathrm{R}} / \mathrm{CG}^{-/-}$mice show normal retinas. $\mathbf{U}-\mathbf{X}: \mathrm{FH} / \mathrm{R}$ mice with anti-C5 monoclonal antibody (mAb) treatment have normal retinas. Y: Quantification of abnormalities on OCT images. Abnormalities, including vessel occlusion, retinal detachment, ONL palisading, inner retinal thinning, and retinal edema, are observed in $\mathrm{FH}^{\mathrm{R} / \mathrm{R}}$ and $\mathrm{FH}^{\mathrm{R} / \mathrm{R}} / \mathrm{C} a \mathrm{R}^{-/-}$mice, but not in $\mathrm{FH}^{\mathrm{W} / \mathrm{W}}, \mathrm{FH}^{\mathrm{R} / \mathrm{R}} / \mathrm{CG}^{-/-}$, and anti- $\mathrm{C} 5 \mathrm{mAb}-$ treated $\mathrm{FH}^{\mathrm{R} / \mathrm{R}}$ mice. Fractions represent ratios of abnormal mice/all experimental mice for each genotype. Fisher exact test reveals a significant association between genotype and likelihood of exhibiting all of the observed pathologic changes. Dotted lines separate different graphs. Bars within each graph are displayed in the same order as genotypes in the key. $n=4 \mathrm{FH}^{\mathrm{R} / \mathrm{R}}$ mice $(\mathbf{F}-\mathbf{J}), \mathrm{FH}^{\mathrm{R} / \mathrm{R}} / \mathrm{C} 5 a R 1^{-1-}$ mice $(\mathbf{K}-\mathbf{0}), \mathrm{FH}^{\mathrm{R} / \mathrm{R}} / \mathrm{C}^{-/-}$mice $(\mathbf{P}-\mathbf{T})$, and $\mathrm{FH}^{\mathrm{W} / \mathrm{W}}$ and $\mathrm{FH} / \mathrm{R} / \mathrm{R} / \mathrm{C} 6^{-/-}$mice $(\mathbf{Y}) ; n=5$ anti-C5 mAb-treated $\mathrm{FH}^{\mathrm{R} / \mathrm{R}}$ mice $(\mathbf{U}-\mathbf{X})$ and $\mathrm{FH}^{\mathrm{R} / \mathrm{R}}$ and anti-C5 mAb-treated $\mathrm{FH}^{\mathrm{R} / \mathrm{R}}$ mice $(\mathbf{Y}) ; n=6 \mathrm{FH}^{\mathrm{R} / \mathrm{R}} / \mathrm{C} 5 a R 1^{-/-}$mice $(\mathbf{Y})$. ${ }^{*} P<0.05$, ${ }^{* * * * P}<0.0001 . \mathrm{Scale}$ bar $=50 \mu \mathrm{m}(\mathbf{A}-\mathbf{D}, \mathbf{F}-\mathbf{I}, \mathbf{K}-\mathbf{N}, \mathbf{P}-\mathbf{S}$, and $\mathbf{U}-\mathbf{X})$. INL, inner nuclear layer; RPE, retinal pigment epithelium.

were then washed three times by transferring the eyecup to a well with $200 \mu \mathrm{L}$ of $1 \times$ TBST, at room temperature for 10 minutes. The secondary antibody was then applied by transferring the eyecup to a well with $100 \mu \mathrm{L}$ of $2 \%$ normal donkey serum in $1 \times$ TBST containing secondary antibody (1:200 dilution) and incubating at room temperature for 2 to 3 hours. The eyecup was then washed three times by transferring to a well with $200 \mu \mathrm{L}$ of $1 \times$ TBST, at room temperature for 10 minutes, then washed once by transfer of the eyecup to a well with $200 \mu \mathrm{L}$ of $1 \times$ TBS, at room temperature for 10 minutes to 
remove the Triton $\mathrm{X}-100$. The retina was then dissected from the RPE/choroid/sclera, flattened with four to six radial incisions, placed on a slide, and dried by wicking surrounding fluid with a Kimwipe (Kimberly-Clark, Irving, TX). Mounting medium was applied to coverslips, which were then inverted onto the slides. Antibodies used were as follows: rabbit anti-mouse CD31 (1:100 dilution; Abcam; ab28364), rat anti-mouse CD31 (1:100 dilution; Abcam; ab7388), BV421 rat anti-mouse CD41 (1:100 dilution; BD Horizon, Franklin Lakes, NJ; 562957), rabbit anti-human fibrinogen/ fluorescein isothiocyanate (1:100 dilution; Dako, Carpinteria, CA; F0111), Cy3-Donkey Anti Rabbit IgG (H+L) (1:200 dilution; Jackson Immuno Research Laboratories, Inc., West Grove, PA; 711-165-152), Cy3-Donkey Anti Rat IgG (H+L) (1:200 dilution; Jackson Immuno Research Laboratories, Inc.; 712-165-153), and Alexa Fluor 488 Donkey Anti Rat $\mathrm{IgG}(\mathrm{H}+\mathrm{L})$ (1:200 dilution; Invitrogen, Waltham, MA; A21208).

The sections were analyzed by fluorescence microscopy with identical exposure parameters (model TE300 microscope; Nikon) with ImagePro software version 1.8.0_112 (Media Cybernetics, Silver Spring, MD).

\section{Spectral Domain OCT Imaging}

Mice were anesthetized, and their pupils were dilated with $1 \%$ tropicamide (Bausch \& Lomb, Inc., Bridgewater, NJ). Mice were placed in the Bioptigen (Durham, NC) AIMRAS holder, and artificial tears were used throughout the procedure to maintain corneal clarity. Optical coherence tomography (OCT) images of the retina were acquired with the Envisu R2200-HR SD-OCT device (Bioptigen) with the reference arm path length set at $950 \mathrm{~mm}$. Image acquisition software built into Envisu R2200-HR SD-OCT was used.

\section{Electron Microscopy}

Retinas (including RPE) fixed in 2\% paraformaldehyde and $2 \%$ glutaraldehyde were postfixed in $1 \%$ osmium tetroxide and $0.1 \mathrm{~mol} / \mathrm{L}$ sodium cacodylate buffer. Specimens were dehydrated and embedded in Epon (Ted Pella, Inc., Redding, CA). Ultrathin sections were cut, stained with uranyl acetate, and examined with a JEOL 1010 transmission electron microscope (Japan Electron Optics Laboratory Company, Mitaka, Tokyo).

\section{Anti-C5 Antibody Treatment}

$\mathrm{FH}^{\mathrm{R} / \mathrm{R}}$ mice were treated with an anti-C5 monoclonal antibody $(\mathrm{mAb})^{16}$ intraperitoneally, $1 \mathrm{mg}$ twice weekly, for 8 weeks starting at 4 weeks of age. The same concentration of MOPC, an isotype-matched $\mathrm{IgG}$, was used as a control.

\section{Statistical Analysis}

The means \pm SD were calculated for each comparison pair using a two-group $t$-test. Statistical analyses for quantification of $\mathrm{C} 3$ immunostaining were performed in GraphPad Prism 6.0 (GraphPad Software, Inc., San Diego, CA) by the one-way analysis of variance with a Tukey posttest comparing means. $P<0.05$ was considered statistically significant for all analyses.

\section{Results}

$\mathrm{FH}^{\mathrm{R} / \mathrm{R}}$ but Not $\mathrm{FH}^{\mathrm{R} / \mathrm{R}} / \mathrm{C \sigma}^{-/-}$Mice Develop Vascular Occlusion and White Spots Visible with in Vivo Retinal Imaging

Retinal imaging was performed on 8-week-old mice (Figure 1) to profile ophthalmic changes in $\mathrm{FH}^{\mathrm{R} / \mathrm{R}}, \mathrm{FH}^{\mathrm{R} / \mathrm{R}} / \mathrm{C} \mathrm{aRl}{ }^{-1-}$, $\mathrm{FH}^{\mathrm{R} / \mathrm{R}} / C 6^{-I-}$, and wild-type $\mathrm{FH}\left(\mathrm{FH}^{\mathrm{W} / \mathrm{w}}\right)$ controls. $\mathrm{FH}^{\mathrm{W} / \mathrm{w}}$ mice had a normal retinal appearance. However, in $\mathrm{FH}^{\mathrm{R} / \mathrm{R}}$ and $\mathrm{FH}^{\mathrm{R} / \mathrm{R}} / \mathrm{C} \mathrm{aRI} \mathrm{I}^{-1-}$ mice, occluded vessels appearing as white lines were observed (Figure 1). In addition, white ischemic patches were found in both $\mathrm{FH}^{\mathrm{R} / \mathrm{R}}$ and $\mathrm{FH}^{\mathrm{R} / \mathrm{R}} / C 5 a R 1^{-1-}$ mice (Figure 1), with variable numbers of white spots (Figure 1). In contrast, $\mathrm{FH}^{\mathrm{R} / \mathrm{R}} / \mathrm{C6}^{-1-}$ mice were rescued, exhibiting normal retinal appearance.

\section{$\mathrm{FH}^{\mathrm{R} / \mathrm{R}}$ Mice Show Delayed and Incomplete Retinal Perfusion}

FA was performed at 8 weeks of age. The whole retina was perfused within 30 seconds in $\mathrm{FH}^{\mathrm{W} / \mathrm{W}}$ and $\mathrm{FH}^{\mathrm{R} / \mathrm{R}} / \mathrm{C6}^{-1-}$ mice, and no fluorescein leakage was observed (Figure 2A). In contrast, both $\mathrm{FH}^{\mathrm{R} / \mathrm{R}}$ and $\mathrm{FH}^{\mathrm{R} / \mathrm{R}} / C 5 a R 1^{-1-}$ mice exhibited delayed and/or incomplete retinal perfusion and fluorescein leakage around the optic nerve head. There was almost no perfusion at even 90 seconds after fluorescein injection in $\mathrm{FH}^{\mathrm{R} / \mathrm{R}}$ mice.

Quantification of abnormal phenotypes was performed using retinal and FA images (Figure 2B). None of the $\mathrm{FH}^{\mathrm{W} / \mathrm{w}}(n=8)$ and $\mathrm{FH}^{\mathrm{R} / \mathrm{R}} / C 6^{-1-}(n=15)$ mice showed retinal abnormalities. In contrast, $82 \%$ of $\mathrm{FH}^{\mathrm{R} / \mathrm{R}}(n=17)$ (Figure $2 \mathrm{~B}$ ) and $50 \%$ of $\mathrm{FH}^{\mathrm{R} / \mathrm{R}} / \mathrm{C} \mathrm{aRl^{-1- }}(n=14)$ mice had retinal vessel occlusion. A total of $88 \%$ of $\mathrm{FH}^{\mathrm{R} / \mathrm{R}}$ and $71 \%$ of $\mathrm{FH}^{\mathrm{R} / \mathrm{R}} / \mathrm{C} \mathrm{aRl^{-l- }}$ mice had white spots. A total of $53 \%$ of $\mathrm{FH}^{\mathrm{R} / \mathrm{R}}$ and $43 \%$ of $\mathrm{FH}^{\mathrm{R} / \mathrm{R}}$ / $C 5 a R 1^{-/-}$mice had ischemic patches. A total of $100 \%$ of FH $^{\mathrm{R} / \mathrm{R}}$ $(n=8)$ and $89 \%$ of $\mathrm{FH}^{\mathrm{R} / \mathrm{R}} / \mathrm{C} \mathrm{aRl} l^{-/}(n=9)$ mice showed perfusion delay. A total of $100 \%$ of $\mathrm{FH}^{\mathrm{R} / \mathrm{R}}$ and $67 \%$ of $\mathrm{FH}^{\mathrm{R} / \mathrm{R}} / \mathrm{C} \mathrm{aRl^{-1- }}$ mice showed vascular leakage. There were significant associations between genotype and likelihood of exhibiting the pathologic changes.

\section{Pharmacologic Blockade of C5 Ameliorates Retinal Pathology in $\mathrm{FH}^{\mathrm{R} / \mathrm{R}}$ Mice}

Because $\mathrm{FH}^{\mathrm{R} / \mathrm{R}} / \mathrm{C6}^{-1-}$ mice were protected from retinal vascular occlusion, the therapeutic efficacy of a systemically administered anti-C5 antibody was tested (Figure 3, D-F, $\mathrm{J}-\mathrm{L}$, and $\mathrm{P}-\mathrm{R}$ ) compared with a mouse IgG1-K monoclonal isotype control (Figure 3, A-C, G-I, and $\mathrm{M}-\mathrm{O}$ ). 
This anti-C5 antibody has been shown previously to block activation of the terminal complement cascade. ${ }^{16}$ Retinal images from a control antibody-treated $\mathrm{FH}^{\mathrm{R} / \mathrm{R}}$ mouse show hypopigmented spots (Figure 3, A and G) with leakage on FA (Figure 3M) at 4 weeks of age. After 4 weeks of treatment with the control antibody, this representative mouse showed pathologic progression that was indicated by ischemic patches (Figure 3B) and by hypopigmented spots (Figure $3 \mathrm{H}$ ). There was also retinal vascular occlusion
(Figure 3, C and I) leading to decreased retinal perfusion (Figure 3O) after 8 weeks of control antibody treatment. In comparison, hypopigmented spots (Figure 3D), ischemic patches (Figure 3J), and occluded vessels (Figure 3J) that were observed before anti-C5 treatment improved after 4 and 8 weeks of treatment, as demonstrated by imaging the same mice over time (Figure 3, E, F, K, and L). Note specifically that the vessel at the 5:30-o'clock position in Figure 3P reopened after anti-C5 treatment (Figure 3, Q and

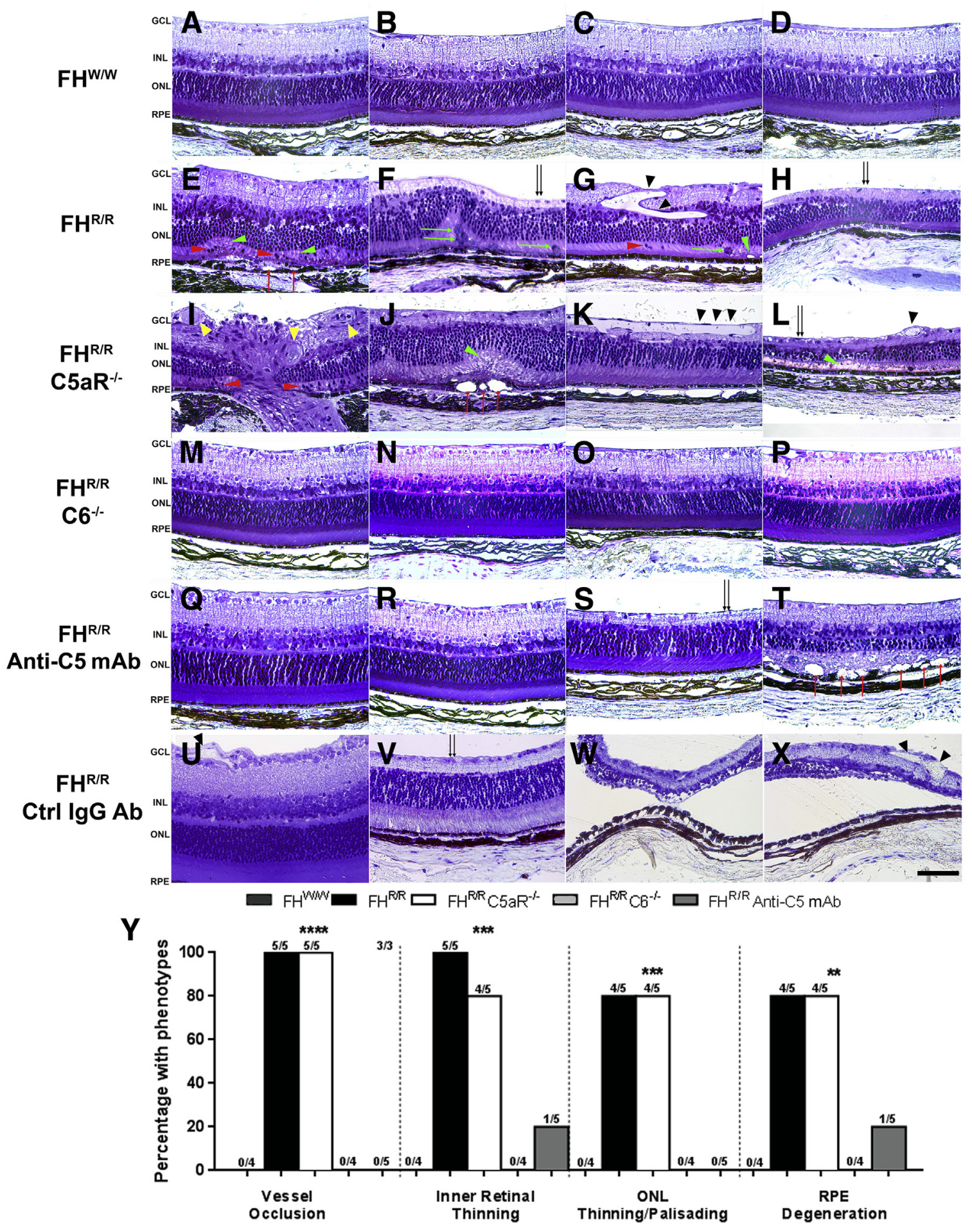


$\mathrm{R}$ ); and leakage around the optic nerve head (Figure 3P) stopped after anti-C5 treatment (Figure 3, Q and R). Only one anti-C5 treated $\mathrm{FH}^{\mathrm{R} / \mathrm{R}}$ mouse $(n=5)$ (Figure $2 \mathrm{~B}$ ) showed vessel occlusion and white spots; the others exhibited no pathologic changes.

\section{Deposition of Fibrin and Platelets Is Found in $\mathrm{FH}^{\mathrm{R} / \mathrm{R}}$ Mice}

To detect clots, immunolabeling of retinal flat mounts was performed with antifibrin and antiplatelet antibodies. Retinal vessels were labeled with vascular endothelial cell (VEC) marker anti-CD31 plus either antifibrin or antiplatelets. Retinas of $\mathrm{FH}^{\mathrm{W} / \mathrm{W}}$ mice appeared normal (Figure 4, A and C). However, strong staining for fibrin and platelets was observed within clots within the retinal vasculature in $\mathrm{FH}^{\mathrm{R} / \mathrm{R}}$ retinas (Figure 4, B and D).

\section{In Vivo OCT Imaging Shows Retinal Protection in $\mathrm{FH}^{\mathrm{R} / \mathrm{R}} / \mathrm{C}^{-/-}$Mice}

OCT imaging was performed to assess retinal morphology in vivo. No abnormalities were found in $\mathrm{FH}^{\mathrm{w} / \mathrm{w}}$ (Figure 5, $\mathrm{A}-\mathrm{E}$ ) and $\mathrm{FH}^{\mathrm{R} / \mathrm{R}} / \mathrm{C6}^{-1-}$ (Figure 5, $\mathrm{P}-\mathrm{T}$ ) mice. In $\mathrm{FH}^{\mathrm{R} / \mathrm{R}}$ and $\mathrm{FH}^{\mathrm{R} / \mathrm{R}} / \mathrm{C} 5 \mathrm{aRl^{-/- }}$ mice, retinal detachment was observed (Figure 5, F, K, and M), as was outer nuclear layer (ONL) palisading in regions of disorganized photoreceptor inner/ outer segments (Figure 5, F, G, and L), thinning of inner retinas (Figure 5, G and $\mathrm{K}$ ) and of total retinas (Figure 5, H and $\mathrm{M}$ ), occluded arteries (Figure $5 \mathrm{H}$ ), as well as retinal edema (Figure 5, I, J, L, N, and O). No abnormalities were observed in anti-C5-treated $\mathrm{FH}^{\mathrm{R} / \mathrm{R}}$ mice (Figure 5, U-X).

Quantification of abnormalities in OCT images was performed (Figure $5 \mathrm{Y}$ ). A total of $100 \%$ of both $\mathrm{FH}^{\mathrm{R} / \mathrm{R}}(n=5)$ (Figure $5 \mathrm{Y})$ and $\mathrm{FH}^{\mathrm{R} / \mathrm{R}} / C 5 a R 1^{-1-}(n=6)$ mice showed retinal detachment, vessel occlusion, and ONL palisading. A total of $80 \%$ of $\mathrm{FH}^{\mathrm{R} / \mathrm{R}}$ mice and $100 \%$ of $\mathrm{FH}^{\mathrm{R} / \mathrm{R}} / C 5 a R 1^{-1-}$ mice showed inner retinal thinning. A total of $60 \%$ of $\mathrm{FH}^{\mathrm{R} / \mathrm{R}}$ and $50 \%$ of $\mathrm{FH}^{\mathrm{R} / \mathrm{R}} / \mathrm{C} a \mathrm{RI}^{-1-}$ mice showed retinal edema. None of the $\mathrm{FH}^{\mathrm{W} / \mathrm{W}}(n=4), \mathrm{FH}^{\mathrm{R} / \mathrm{R}} / C 6^{-1-}(n=4)$, and anti-C5-treated $(n=5)$ mice had these abnormalities.
There were significant associations between genotype and likelihood of exhibiting pathologic changes.

\section{Retinal Ischemia and Degeneration in $\mathrm{FH}^{\mathrm{R} / \mathrm{R}}$ Mice}

Morphologic analysis was performed at 8 weeks of age. Plastic sections of $\mathrm{FH}^{\mathrm{W} / \mathrm{W}}$ (Figure $6, \mathrm{~A}-\mathrm{D}$ ) and $\mathrm{FH}^{\mathrm{R} / \mathrm{R}} / C 6^{-I-}$ (Figure 6, M-P) mice revealed normal retinal histology. In contrast, sections from $\mathrm{FH}^{\mathrm{R} / \mathrm{R}}$ (Figure 6, E-H) and $\mathrm{FH}^{\mathrm{R} / \mathrm{R}}$ / $\mathrm{C} \mathrm{aRl} \mathrm{I}^{-1-}$ (Figure 6, I-L) mice revealed occluded arteries and veins (Figure 6I), dilated veins (Figure 6, G, K, and L), retinal thinning (Figure 6, F, H, and $\mathrm{L}$ ), ONL palisading (Figure 6, E, F, and J), vacuolar degeneration of photoreceptor inner/outer segments (Figure 6, E, G, J, and L), migration of photoreceptor nuclei toward the RPE (Figure 6, E, G, and I), migration of RPE cells toward the ONL (Figure 6, F and G), and vacuolar degeneration of the RPE (Figure 6, E and J). Among the five anti-C5-treated $\mathrm{FH}^{\mathrm{R} / \mathrm{R}}$ mice, one mouse showed retinal thinning (Figure 6S) and another one showed focal RPE vacuolization in the peripheral retina close to the ora serrata (Figure 6T). The other three exhibited normal retinas (Figure 6, Q and $\mathrm{R}$ ). In comparison, control antibody-treated $\mathrm{FH}^{\mathrm{R} / \mathrm{R}}$ mice $(n=3)$ showed vein dilation (Figure 6, U and $\mathrm{X}$ ) and retinal thinning (Figure 6V). One mouse showed minimal degeneration (Figure $6 \mathrm{U}$ ), whereas another exhibited extensive total retinal thinning (Figure 6, W and $\mathrm{X}$ ). One possibility for this observation is that the $\mathrm{FH}^{\mathrm{R} / \mathrm{R}}$ mutation may be associated with variable severity of retinal degeneration. This variability does not track with sex. However, the three control antibody-treated $\mathrm{FH}^{\mathrm{R} / \mathrm{R}}$ mice were the ones that survived the full 8 weeks of antibody treatment; another five only survived between 1 and 5 weeks after treatment initiation. Therefore, there may be selection bias in that the three healthiest control antibody -treated mice were analyzed, including a minimally affected one.

Quantification showed that $100 \%$ of both $\mathrm{FH}^{\mathrm{R} / \mathrm{R}}(n=5)$ (Figure $6 \mathrm{Y}$ ) and $\mathrm{FH}^{\mathrm{R} / \mathrm{R}} / \mathrm{C5aRl}^{-/-}(n=5)$ (Figure $6 \mathrm{Y}$ ) mice had vessel occlusion. A total of $100 \%$ of $\mathrm{FH}^{\mathrm{R} / \mathrm{R}}$ and $80 \%$ of $\mathrm{FH}^{\mathrm{R} / \mathrm{R}} / \mathrm{C} \mathrm{aRl^{-1- }}$ mice had retinal thinning. A total of $80 \%$ of both $\mathrm{FH}^{\mathrm{R} / \mathrm{R}}$ and $\mathrm{FH}^{\mathrm{R} / \mathrm{R}} / C 5 a R 1^{-1-}$ mice had ONL

\footnotetext{
Figure 6 Photomicrographs of plastic sections of mouse retinas. Each image is representative of its source eye, as pathologic severity does not noticeably change with retinal location. A-D: $\mathrm{FH} / \mathrm{W}$ mice have normal retinas. $\mathbf{E}-\mathbf{L}$ : In contrast, $\mathrm{FH} / \mathrm{R} / \mathrm{R}(\mathbf{E}-\mathbf{H})$ and $\mathrm{FH}^{\mathrm{R} / \mathrm{R}} / \mathrm{C} 5 a R 1^{-/-}(\mathrm{I}-\mathbf{L})$ mice exhibit palisading of the outer nuclear layer (ONL; E, F, and J), vacuolar degeneration of photoreceptor inner/outer segment (green arrowheads), migration of photoreceptor nuclei toward the retinal pigment epithelium (RPE; red arrowheads), migration of RPE cells toward the ONL (green arrows), vacuolar RPE degeneration (red arrows in $\mathbf{E}$ and $\mathbf{J}$ ), dilated veins (black arrowheads in $\mathbf{G}, \mathbf{K}$, and $\mathbf{L}$ ), occluded arteries and veins (yellow arrowheads), and retinal thinning (double black arrows in $\mathbf{F}$, $\mathbf{H}$, and $\mathbf{L}$ ). $\mathbf{M}-\mathbf{P}: \mathrm{FH}^{\mathrm{R} / \mathrm{R}} / \mathrm{C \sigma}^{-/-}$mice show normal retinas. Q-T: $\mathrm{FH}^{\mathrm{R} / \mathrm{R}}$ mice with anti-C5 monoclonal antibody (mAb) treatment have normal retinas, except for one mouse that shows focal thinning of the retina (black double arrows in S) and another mouse with focal RPE vacuolization in the peripheral retina (red arrows in $\mathbf{T}$ ). $\mathbf{U}-\mathbf{X}$ : Control (Ctrl) antibody-treated $\mathrm{FH}^{\mathrm{R} / \mathrm{R}}$ mice ( $\mathbf{W}$ and $\mathbf{X}$ from same mouse) show vein dilation (black arrowheads in $\mathbf{U}$ and $\mathbf{X}$ ) and retinal thinning (black double arrows in $\mathbf{V}$ ). $\mathbf{W}$ and $\mathbf{X}$ : One mouse showed extensive total retinal thinning. $\mathbf{Y}$ : Quantification of abnormalities in images of plastic sections. Abnormalities, including vessel occlusion, inner retinal thinning, $0 \mathrm{NL}$ thinning/palisading, and $\mathrm{RPE}$ degeneration, are observed in $\mathrm{FH}^{\mathrm{R} / \mathrm{R}}$ and $\mathrm{FH}{ }^{\mathrm{R} / \mathrm{R}}$ /

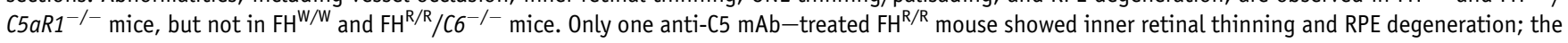
others exhibited no pathologic changes. Fractions represent ratios of abnormal mice/all experimental mice for each genotype. Fisher exact test revealed a significant association between genotype and likelihood of exhibiting all of the observed pathologic changes. Dotted lines separate different graphs. $n=4$

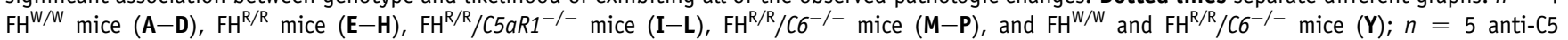
$\mathrm{mAb}$-treated $\mathrm{FH}^{\mathrm{R} / \mathrm{R}}$ mice $(\mathbf{Q}-\mathbf{T}), \mathrm{FH}^{\mathrm{R} / \mathrm{R}}, \mathrm{FH}^{\mathrm{R} / \mathrm{R}} / \mathrm{CS} a 1^{-1-}(\mathbf{Y})$, and anti-C5 mAb-treated $\mathrm{FH}^{\mathrm{R} / \mathrm{R}}$ mice; $n=3$ Ctrl antibody-treated $\mathrm{FH}^{\mathrm{R} / \mathrm{R}}$ mice $(\mathbf{U}-\mathbf{X})$. ${ }^{* *} P<0.01,{ }^{* * *} P<0.001$, and ${ }^{* * * *} P<0.0001$. Scale bar $=50 \mu \mathrm{m}(\mathbf{A}-\mathbf{X}) . \mathrm{GCL}$, ganglion cell layer; INL, inner nuclear layer.
} 


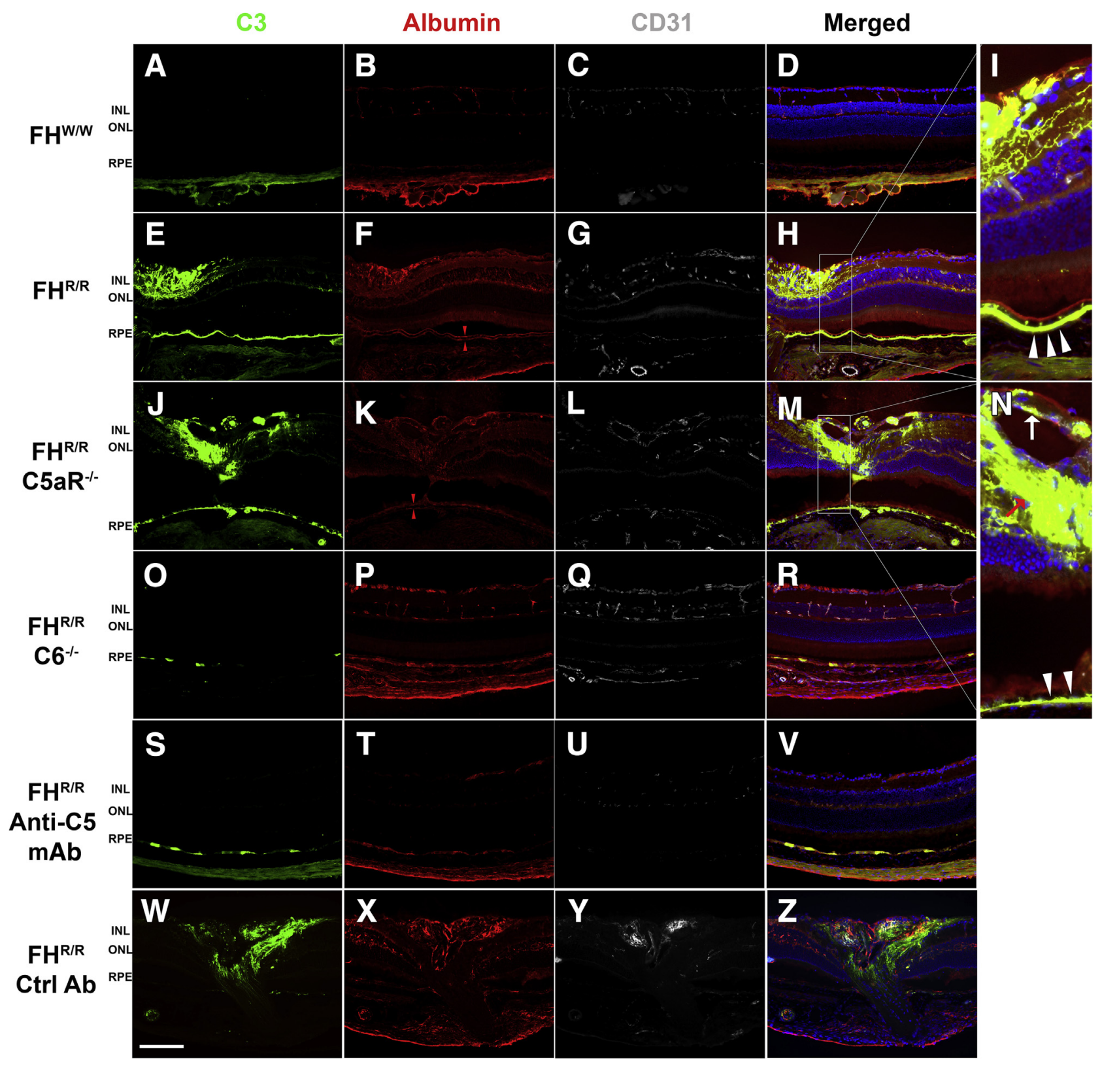

\section{AA}

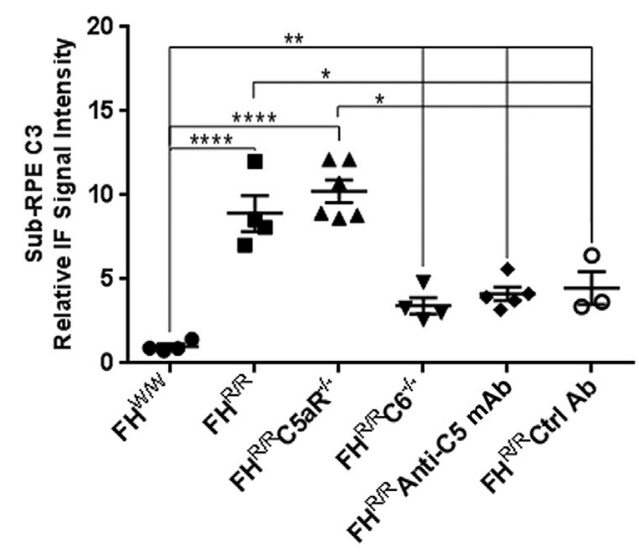

BB

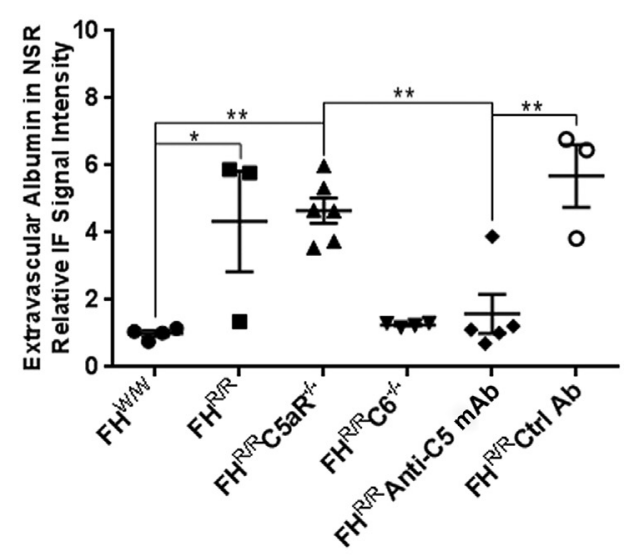


thinning/palisading and RPE degeneration. None of the $\mathrm{FH}^{\mathrm{W} / \mathrm{w}}(n=4)$ and $\mathrm{FH}^{\mathrm{R} / \mathrm{R}} / C 6^{-l-}(n=4)$ mice showed these pathologies. Only one anti-C5-treated $\mathrm{FH}^{\mathrm{R} / \mathrm{R}}$ mouse exhibited inner retinal thinning and RPE degeneration $(n=$ 5) (Figure 6Y). There were significant associations between genotype and likelihood of exhibiting pathologic changes.

\section{Extravascular Albumin and C3 Leakage into the Neural Retinas of $\mathrm{FH}^{\mathrm{R} / \mathrm{R}}$ Mice}

Albumin labeling was observed exclusively within the retinal vasculature in $\mathrm{FH}^{\mathrm{W} / \mathrm{W}}$ (Figure $7 \mathrm{~B}$ ), $\mathrm{FH}^{\mathrm{R} / \mathrm{R}} / \mathrm{C6}^{-1-}$ (Figure $7 \mathrm{P}$ ), and anti-C5-treated $\mathrm{FH}^{\mathrm{R} / \mathrm{R}}$ (Figure $7 \mathrm{~T}$ ) mice. In contrast, albumin labeling was seen outside of the vasculature in $\mathrm{FH}^{\mathrm{R} / \mathrm{R}}$ (Figure $7 \mathrm{~F}$ ), $\mathrm{FH}^{\mathrm{R} / \mathrm{R}} / \mathrm{C} 5 a R 1^{-1-}$ (Figure $7 \mathrm{~K}$ ), and control antibody-treated $\mathrm{FH}^{\mathrm{R} / \mathrm{R}}$ (Figure 7X) mice, indicating vascular leakage.

Immunolabeling was performed with anti-C 3 to test for complement deposition. There was no $\mathrm{C} 3$ labeling in $\mathrm{FH}^{\mathrm{W} / \mathrm{W}}$ mice $(n=4)$ (Figure 7A). However, there was prominent subRPE C3 labeling in $\mathrm{FH}^{\mathrm{R} / \mathrm{R}}(n=4)$ (Figure 7E) and $\mathrm{FH}^{\mathrm{R} / \mathrm{R}} /$ $\mathrm{C5aRl}^{-1-}(n=6)$ (Figure $\left.7 \mathrm{~J}\right)$ mice. Staining with CD31 antibody is shown (Figure 7, C, G, L, Q, U and Y). Merged channels are shown (Figure 7, D, H, I, M, N, R, V and Z). Higher-magnification images of sections colabeled with a CD31 antibody against VECs showed that C3 colocalized with retinal VECs (Figure $7 \mathrm{~N}$ ) and was also present outside vessels within the neurosensory retina (NSR) (Figure $7 \mathrm{~N}$ ). Patchy subRPE C3 labeling was still observed in $\mathrm{FH}^{\mathrm{R} / \mathrm{R}} / C 6^{-1-}(n=4)$ (Figure 7O) and anti-C5-treated $\mathrm{FH}^{\mathrm{R} / \mathrm{R}}(n=5)$ (Figure 7S) mice. Surprisingly, control antibody - treated $\mathrm{FH}^{\mathrm{R} / \mathrm{R}}$ mice $(n=$ 3) (Figure 7W) had minimal sub-RPE labeling. C3 labeling in the neural retina was similar to the albumin leakage patterns, consistent with $\mathrm{C} 3$ leaking into the neural retinas from the vasculature.

Pixel density analysis revealed a significantly higher subRPE C3 signal in $\mathrm{FH}^{\mathrm{R} / \mathrm{R}}$ and $\mathrm{FH}^{\mathrm{R} / \mathrm{R}} / \mathrm{C} \mathrm{aR} 1^{-/-}$mice relative to the other groups (Figure 7AA). In comparison, $\mathrm{FH}^{\mathrm{W} / \mathrm{W}}$ mice had lower signal than all other groups. Notably, there was a reduction in sub-RPE C3 signal intensity, relative to $\mathrm{FH}^{\mathrm{R} / \mathrm{R}}$ mice, in both anti-C5-treated $\mathrm{FH}^{\mathrm{R} / \mathrm{R}}$ and control antibody-treated $\mathrm{FH}^{\mathrm{R} / \mathrm{R}}$ mice, suggesting a possible inhibition of sub-RPE C3 deposition conferred by antibody treatment in a nonepitope-specific manner. Regarding extravascular albumin in the NSR, the $\mathrm{FH}^{\mathrm{R} / \mathrm{R}}$ group (with the exception of one mouse) along with the $\mathrm{FH}^{\mathrm{R} / \mathrm{R}}$ / $C 5 a 1^{-1-}$ and control antibody-treated $\mathrm{FH}^{\mathrm{R} / \mathrm{R}}$ groups exhibited higher albumin signal in the NSR than the other groups (Figure 7BB). Only one of five anti-C5-treated $\mathrm{FH}^{\mathrm{R} / \mathrm{R}}$ mice had a relatively high albumin signal.

\section{Electron Microscopy Reveals Irregular VECs Associated with Constriction of Superficial Retinal and Choroidal Vasculature of $\mathrm{FH}^{\mathrm{R} / \mathrm{R}}$ Mice}

To better determine the nature of the observed vascular occlusion, ultrastructural analysis was performed using electron microscopy. Relative to $\mathrm{FH}^{\mathrm{W} / \mathrm{W}}$ mice $(n=4)$ (Figure $8, \mathrm{~A}-\mathrm{C}), \mathrm{FH}^{\mathrm{R} / \mathrm{R}}$ mice $(n=5)$ (Figure $8, \mathrm{D}-\mathrm{G}$ ) exhibited decreased lumen diameters of both choroidal capillary (Figure 8D) and retinal vessels (Figure 8, E-G) and irregularly contoured VECs (Figure 8, D-G).

\section{Discussion}

Herein, we report a mouse model of retinal vascular occlusion and ischemic retinopathy. Key pathologic changes in eyes of $\mathrm{FH}^{\mathrm{R} / \mathrm{R}}$ mice include retinal vascular occlusion leading to atrophic thinning of the retina. These features are also found in human retinal vascular occlusive disorders. Moreover, although previous mouse models of retinal vascular disease have used photothermal damage and photodynamic activation of rose bengal to induce occlusion, ${ }^{17}$ this model uniquely features occlusion secondary to a mutation in a complement regulator gene.

The renal phenotypes of $\mathrm{FH}^{\mathrm{R} / \mathrm{R}}$ mice share features of human aHUS. ${ }^{13}$ The W1206R mutation in mouse $\mathrm{FH}$ is equivalent to the W1183R mutation in human FH found in some aHUS patients. ${ }^{8-10}$ This mutation impairs FH interaction with the host cell surface but does not affect the complement-regulating function of $\mathrm{FH}$. Thus, one major consequence of this and other similar mutations in FH Cterminus is susceptibility of host cells, particularly kidney and retinal endothelial cells, to complement-mediated injury

Figure 7 Fluorescence photomicrographs showing C3, albumin, and CD31 localization. A-D: In FH/W mice, no C3 labeling is seen in the retina and retinal pigment epithelium (RPE). E-N: However, there is prominent retinal and sub-RPE C3 labeling in $\mathrm{FH}^{\mathrm{R} / \mathrm{R}}(\mathbf{E}-\mathbf{I})$ and $\mathrm{FH} / \mathrm{R} / \mathrm{C5} a \mathrm{R} 1^{-/-}(\mathbf{J}-\mathbf{N})$ mice. $\mathbf{0}-\mathbf{V}$ : No retinal labeling and patchy sub-RPE C3 labeling are seen in $\mathrm{FH}^{\mathrm{R} / \mathrm{R}} / \mathrm{C}^{-/-}(\mathbf{O}-\mathbf{R})$ and anti-C5 monoclonal antibody $(\mathrm{mAb})-$ treated $\mathrm{FH} / \mathrm{R} / \mathrm{R}(\mathbf{S}-\mathbf{V})$ mice. W-Z: Control (Ctrl) antibody-treated $\mathrm{FH}^{\mathrm{R} / \mathrm{R}}$ mice exhibit retinal C3 labeling similar to $\mathrm{FH}^{\mathrm{R} / \mathrm{R}}$ and $\mathrm{FH}^{\mathrm{R} / \mathrm{R}} / \mathrm{C} 5 a R 1^{-/-}$mice, but patchy sub-RPE labeling. $\mathbf{B}, \mathbf{P}$, and $\mathrm{T}$ : Albumin labeling is exclusively within the retinal vasculature in $\mathrm{FH}^{\mathrm{W} / \mathrm{W}}(\mathbf{B}), \mathrm{FH}^{\mathrm{R} / \mathrm{R}} / \mathrm{CG}^{-/-}(\mathbf{P})$, and anti-C5 mAb-treated $\left.\mathrm{FH} / \mathrm{R} / \mathrm{T}\right)$ mice. F, I, $\mathbf{K}$, and $\mathbf{N}$ : C3 also localizes to the basolateral side of the RPE (white arrowheads), and albumin localizes to both apical and basolateral sides of RPE cells (red arrowheads). F, K, and X: Extravascular albumin labeling is seen in $\mathrm{FH}^{\mathrm{R} / \mathrm{R}}(\mathbf{F}), \mathrm{FH}^{\mathrm{R} / \mathrm{R}} / \mathrm{CSAR1}^{-/-}(\mathbf{K})$, and control antibody-treated $\mathrm{FH}^{\mathrm{R} / \mathrm{R}}(\mathbf{X})$ mice, indicating vascular leakage. $\mathrm{N}$ : Highermagnification shows colabeling of C3 with endothelial cells (white arrow) and extravascular C3 labeling (red arrow). AA: Quantification of sub-RPE C3 signal intensity reveals that $\mathrm{FH}^{\mathrm{R} / \mathrm{R}}$ and $\mathrm{FH}^{\mathrm{R} / \mathrm{R}} / \mathrm{C5} 5 \mathrm{AR} 1^{-/-}$mice have significantly higher signals than the other groups, whereas $\mathrm{FH} / \mathrm{W}$ mice have a lower signal than all other groups. BB: Quantification of extravascular retinal albumin signal intensity shows that $\mathrm{FH}^{\mathrm{R} / \mathrm{R}}, \mathrm{FH}^{\mathrm{R} / \mathrm{R}} / \mathrm{C} \mathrm{aR} 1^{-/-}$, and control antibody-treated $\mathrm{FH} / \mathrm{R} / \mathrm{R}$ mice have significantly higher signals than $\mathrm{FH}^{\mathrm{W} / \mathrm{W}}$ and $\mathrm{FH}^{\mathrm{R} / \mathrm{R}} / \mathrm{C \sigma}^{-/-}$mice. All anti-C5 mAb-treated $\mathrm{FH}^{\mathrm{R} / \mathrm{R}}$ mice, except one, and one $\mathrm{FH}^{\mathrm{R} / \mathrm{R}}$ mouse have intensities

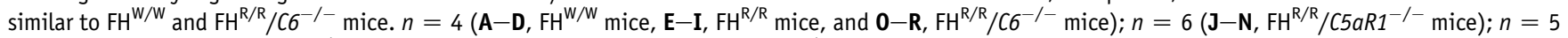
$\left(\mathbf{S}-\mathbf{V}\right.$, anti-C5 mAb-treated $\mathrm{FH}^{\mathrm{R} / \mathrm{R}}$ mice) $; n=3\left(\mathbf{W}-\mathbf{Z}\right.$, Ctrl antibody-treated $\mathrm{FH}^{\mathrm{R} / \mathrm{R}}$ mice $)$. Scale bar $=50 \mu \mathrm{m}(\mathbf{A}-\mathbf{H}, \mathbf{J}-\mathbf{M}$, and $\mathbf{0}-\mathbf{Z}) .{ }^{*} P<0.05,{ }^{* *} P<0.01$, and $* * * * P<0.0001$. INL, inner nuclear layer; NSR, neurosensory retina; $0 N L$, outer nuclear layer. 

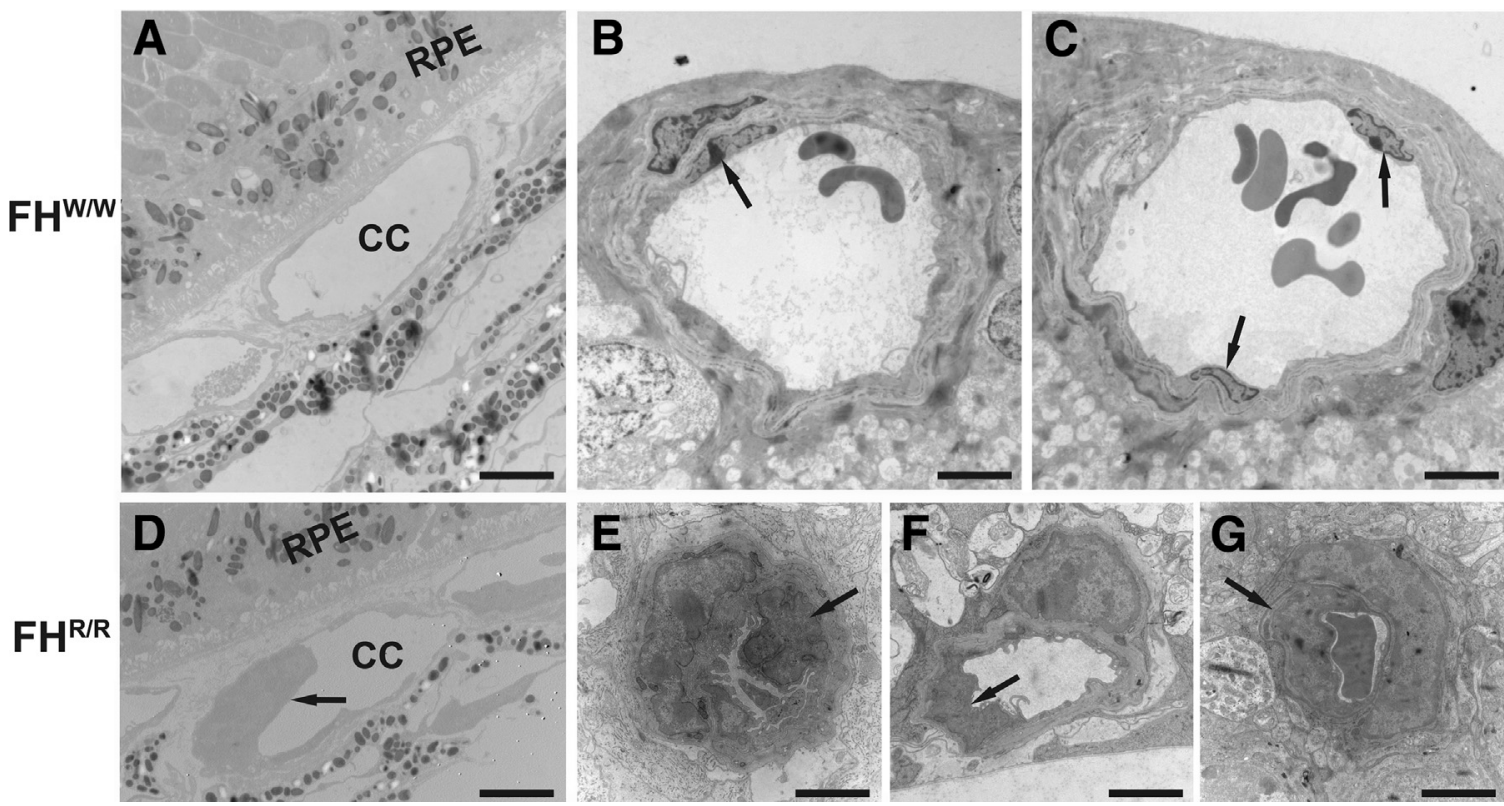

Figure 8 Electron micrographs showing choroidal (A and $\mathbf{D})$ and superficial retinal vessels (B, C, E, F, and $\mathbf{G})$. All sections were taken from near the optic nerve. Relative to $\mathrm{FH}^{\mathrm{W} / \mathrm{W}}$ mice $(\mathbf{A}-\mathbf{C}), \mathrm{FH}^{\mathrm{R} / \mathrm{R}}$ mice $(\mathbf{D}-\mathbf{G})$ exhibit enlarged vascular endothelial cells (VECS) (D), narrowed vessel lumens, irregularly contoured VECs, and enlarged pericytes in small arterioles (E-G). Arrows indicate VECs. $n=4(\mathbf{A}-\mathbf{C}) ; n=5(\mathbf{D}-\mathbf{G})$. Scale bar $=4 \mu \mathrm{m}(\mathbf{A}-\mathbf{G})$. CC, choroidal capillary; $\mathrm{RPE}$, retinal pigment epithelium.

with increased risk of thrombotic vasculopathy. Glomerular thrombotic microangiopathy is the pathologic hallmark of aHUS. ${ }^{18}$ Interestingly, ocular involvement in both adult ${ }^{19-21}$ and pediatric patients ${ }^{20,22-26}$ with aHUS has been reported. It is likely that most of the ocular findings in $\mathrm{FH}^{\mathrm{R} / \mathrm{R}}$ mice occur secondary to thrombotic microangiopathy after MACmediated VEC damage because these had extensive retinal nonperfusion and vascular leakage on FA whereas $\mathrm{FH}^{\mathrm{R} / \mathrm{R}}$ mice that also had deficiency in C6, a component of the MAC, had normal retinas. Terminal complement activation most likely damaged VEC and caused stenosis of vessels, as observed by electron microscopy, predisposing the vessel wall to thrombosis, which was observed in retinal flat mounts immunolabeled with antifibrin and antiplatelet antibodies.

Neutrophils or monocytes are activated by C5a via the C5aR1, which is highly expressed on these cells. Activation of the $\mathrm{C} 5 \mathrm{a} / \mathrm{C} 5 \mathrm{aR}$ pathway causes release of tissue factor to participate in clot formation in both capillaries and large blood vessels. ${ }^{27,28}$ Deletion of $C 5 a R 1$ from $\mathrm{FH}^{\mathrm{R} / \mathrm{R}}$ mice prevented macrovessel thrombosis in several organs, such as the liver and spleen, but did not prevent thrombotic microangiopathy in the kidney. ${ }^{29}$ Results presented herein suggested that the $\mathrm{C} 5 \mathrm{a} / \mathrm{C} 5 \mathrm{aR}$ pathway is similarly not involved in the retinal pathologies of $\mathrm{FH}^{\mathrm{R} / \mathrm{R}}$ mice; instead, MAC component $C 6$ was involved. Thus, it is likely that both the retinal phenotypes and kidney thrombotic microangiopathy are MAC dependent. It is possible that direct injury by MAC leads to endothelial swelling and narrowing of capillary lumens, as we have observed in the retinas of $\mathrm{FH}^{\mathrm{R} / \mathrm{R}}$ mice (Figure 8). Released hemoglobin from sheared and fragmented red blood cells passing through the narrowed lumen can scavenge nitric oxide, a major vasoprotective and platelet activation inhibitory molecule, further promoting the occurrence of retinal thrombosis. ${ }^{30}$

Interestingly, C3 label in the retina colocalizes with extravascular albumin in $\mathrm{FH}^{\mathrm{R} / \mathrm{R}}$ and $\mathrm{FH}^{\mathrm{R} / \mathrm{R}} / \mathrm{C} a \mathrm{RI}^{-/-}$neural retinas, indicating leakage across a damaged blood-retinal barrier, consistent with the leakage shown by FA. In $\mathrm{FH}^{\mathrm{R} / \mathrm{R}} /$ $\mathrm{C6}^{-/-}$and anti-C5 $\mathrm{mAb}-$ treated $\mathrm{FH}^{\mathrm{R} / \mathrm{R}}$ mice, probably because of the downstream blockade of MAC formation, there was less damage to VEC and no leakage of albumin or C3 into the NSR. However, C3 label on the basal RPE most likely occurs because of the loss of RPE membrane protection by FH. Treatment with anti-C5 mAb diminished this labeling. However, this effect of anti-C5 mAb is unlikely to be related to its MAC-inhibiting activity as the control antibody had a similar effect. Whether this represented a nonspecific anti-inflammatory effect similar to i.v. Ig treatment remains to be investigated.

In patients, Purtscher and Purtscher-like retinopathy are rare occlusive thromboembolic retinopathies. Purtscher retinopathy refers to a traumatic etiology, whereas Purtscher-like retinopathy has nontraumatic causes. ${ }^{31}$ Although the pathogeneses of Purtscher and Purtscher-like retinopathy are multifactorial, embolization of the retinal circulation has been proposed as the common cause of the ocular findings. ${ }^{32-36}$ Most patients with Purtscher-like retinopathy show cotton wool spots and intraretinal hemorrhages on funduscopic examinations, and there is evidence of occlusive thromboembolic retinopathy with nonperfused areas and fluorescein dye leakage from retinal arterioles, capillaries, venules, and the optic disk. . $^{31,33,37}$ Previous reports showed that select patients with Purtscher-like retinopathy were successfully treated with i.v. 
eculizumab, ${ }^{2,32}$ a humanized monoclonal anti-C5 mAb that prevents activation of the terminal complement cascade, analogous to the protective effect of anti-C5 mAb in our $\mathrm{FH}^{\mathrm{R} / \mathrm{R}}$ mice.

These anti-C5 mAb therapy results indicate that C5 activation participates in the pathophysiology of vascular occlusion and ischemic retinopathy in $\mathrm{FH}^{\mathrm{R} / \mathrm{R}}$ mice. The finding that an anti-C5 mAb protects against retinal thrombosis and ischemia in this aHUS model highlights differences between this model and age-related macular degeneration. For age-related macular degeneration patients, i.v. anti-C5 therapy with eculizumab was not clinically effective. These findings also highlight the disparate retinal effects of the $F H$ W1206R mutation and the age-related macular degeneration-associated $\mathrm{Y} 402 \mathrm{H}$ mutation. The study supports the concept that anti-C5 antibodies may represent a valuable therapeutic approach, particularly in patients with Purtscher-like retinopathy in whom complement is the primary driving factor. It will be of interest to determine whether complement may play a role in additional patients with retinal vascular thrombosis.

\section{References}

1. Hayreh SS: Ocular vascular occlusive disorders: natural history of visual outcome. Prog Retin Eye Res 2014, 41:1-25

2. Sampedro López A, Domínguez Moro B, Baltar Martin JM, Garcia Monteavaro C, Barbón García JJ: Ocular involvement in atypical haemolytic uraemic syndrome. Arch Soc Esp Oftalmol 2017, 92: 594-597

3. Greenwood GT: Case report of atypical hemolytic uremic syndrome with retinal arterial and venous occlusion treated with eculizumab. Int Med Case Rep J 2015, 8:235-239

4. David R, Hochberg-Klein S, Amer R: Resolution of ocular involvement with systemic eculizumab therapy in atypical hemolytic-uremic syndrome. Eye 2013, 27:997-998

5. Fearon DT: Regulation by membrane sialic acid of $\beta 1 \mathrm{H}$-dependent decay-dissociation of amplification C3 convertase of the alternative complement pathway. Proc Natl Acad Sci U S A 1978, 75:1971-1975

6. Józsi M, Zipfel PF: Factor H family proteins and human diseases. Trends Immunol 2008, 29:380-387

7. Rodríguez de Córdoba S, Esparza-Gordillo J, Goicoechea de Jorge E, Lopez-Trascasa M, Sánchez-Corral P: The human complement factor $\mathrm{H}$ : functional roles, genetic variations and disease associations. Mol Immunol 2004, 41:355-367

8. Caprioli J, Bettinaglio P, Zipfel PF, Amadei B, Daina E, Gamba S, Skerka C, Marziliano N, Remuzzi G, Noris M; Italian Registry of Familial and Recurrent HUS/TTP: The molecular basis of familial hemolytic uremic syndrome: mutation analysis of factor $\mathrm{H}$ gene reveals a hot spot in short consensus repeat 20. J Am Soc Nephrol 2001, 12: 297-307

9. Pérez-Caballero D, González-Rubio C, Gallardo ME, Vera M, López-Trascasa M, Rodríguez de Córdoba S, Sánchez-Corral P: Clustering of missense mutations in the $\mathrm{C}$-terminal region of factor $\mathrm{H}$ in atypical hemolytic uremic syndrome. Am J Hum Genet 2001, 68:478-484

10. Richards A, Buddles MR, Donne RL, Kaplan BS, Kirk E, Venning MC, Tielemans CL, Goodship JA, Goodship TH: Factor H mutations in hemolytic uremic syndrome cluster in exons 18-20, a domain important for host cell recognition. Am J Hum Genet 2001, 68: 485-490
11. Raychaudhuri S, Iartchouk O, Chin K, Tan PL, Tai A, Ripke S, Gowrisankar S, Vemuri S, Montgomery K, Yu Y, Reynolds R, Zack DJ, Campochiaro B, Campochiaro P, Katsanis N, Daly MJ, Seddon JM: A rare penetrant mutation in $\mathrm{CFH}$ confers high risk of agerelated macular degeneration. Nat Genet 2011, 43:1232-1236

12. Triebwasser MP, Roberson EDO, Yu Y, Schramm EC, Wagner EK, Raychaudhuri S, Seddon JM, Atkinson JP: Rare variants in the functional domains of complement factor $\mathrm{H}$ are associated with age-related macular degeneration. Invest Ophthalmol Vis Sci 2015, 56: 6873-6878

13. Ueda Y, Mohammed I, Song D, Gullipalli D, Zhou L, Sato S, Wang Y, Gupta S, Cheng Z, Wang H, Bao J, Mao Y, Brass L, Zheng XL, Miwa T, Palmer M, Dunaief J, Song W-C: Murine systemic thrombophilia and hemolytic uremic syndrome from a factor $\mathrm{H}$ point mutation. Blood 2017, 129:1184-1196

14. Lesher AM, Zhou L, Kimura Y, Sato S, Gullipalli D, Herbert AP, Barlow PN, Eberhardt HU, Skerka C, Zipfel PF, Hamano T, Miwa T, Tung KS, Song W-C: Combination of factor $\mathrm{H}$ mutation and properdin deficiency causes severe C3 glomerulonephritis. J Am Soc Nephrol 2013, 24:53-65

15. Höpken UE, Lu B, Gerard NP, Gerard C: The C5a chemoattractant receptor mediates mucosal defence to infection. Nature 1996, 383: $86-89$

16. Williams AL, Gullipalli D, Ueda Y, Sato S, Zhou L, Miwa T, Tung KS, Song W-C: C5 inhibition prevents renal failure in a mouse model of lethal C3 glomerulopathy. Kidney Int 2017, 91:1386-1397

17. Ebneter A, Agca C, Dysli C, Zinkernagel MS: Investigation of retinal morphology alterations using spectral domain optical coherence tomography in a mouse model of retinal branch and central retinal vein occlusion. PLoS One 2015, 10:e0119046

18. Keir L, Coward RJM: Advances in our understanding of the pathogenesis of glomerular thrombotic microangiopathy. Pediatr Nephrol 2011, 26:523-533

19. Eberhard OK, Labjuhn SO, Olbricht CJ: Ocular involvement in haemolytic uraemic syndrome: case report and review of the literature. Nephrol Dial Transplant 1995, 10:266-269

20. Larakeb A, Leroy S, Frémeaux-Bacchi V, Montchilova M, Pelosse B, Dunand O, Deschênes G, Bensman A, Ulinski T: Ocular involvement in hemolytic uremic syndrome due to factor $\mathrm{H}$ deficiency-are there therapeutic consequences? Pediatr Nephrol 2007, 22:1967-1970

21. Sandhu H, Vavvas D: Bilateral tractional retinal detachment in a patient with hemolytic-uremic syndrome. J AAPOS 2015, 19: 484-486

22. Lauer AK, Klein ML, Kovarik WD, Palmer EA: Hemolytic uremic syndrome associated with Purtscher-like retinopathy. Arch Ophthalmol 1998, 116:1119-1120

23. Krott R, Querfeld U, Bartz-Schmidt KU, Hammers H, Hammers W, Heimann K: Progressive subretinal fibrosis in a child following hemolytic uremic syndrome. Retina 1999, 19:77-79

24. Sheth KJ, Swick HM, Haworth N: Neurological involvement in hemolytic-uremic syndrome. Ann Neurol 1986, 19:90-93

25. Siegler RL, Brewer ED, Swartz M: Ocular involvement in hemolyticuremic syndrome. J Pediatr 1988, 112:594-597

26. Sturm V, Menke MN, Landau K, Laube GF, Neuhaus TJ: Ocular involvement in paediatric haemolytic uraemic syndrome. Acta Ophthalmol 2010, 88:804-807

27. Ritis K, Doumas M, Mastellos D, Micheli A, Giaglis S, Magotti P, Rafail S, Kartalis G, Sideras P, Lambris JD: A novel C5a receptortissue factor cross-talk in neutrophils links innate immunity to coagulation pathways. J Immunol 2006, 177:4794-4802

28. Kourtzelis I, Markiewski MM, Doumas M, Rafail S, Kambas K, Mitroulis I, Panagoutsos S, Passadakis P, Vargemezis V, Magotti P, Qu H, Mollnes TE, Ritis K, Lambris JD: Complement anaphylatoxin C5a contributes to hemodialysis-associated thrombosis. Blood 2010, 116:631-639

29. Ueda Y, Miwa T, Ito D, Kim H, Sato S, Gullipalli D, Zhou L, Golla M, Song D, Dunaief JL, Palmer M, Song W-C: Differential contribution of 
C5aR and C5b-9 pathways to renal TMA and macrovascular thrombosis in mice carrying an aHUS-related factor $\mathrm{H}$ mutation. Kidney Int [In press]

30. Suhr F, Brenig J, Müller R, Behrens H, Bloch W, Grau M: Moderate exercise promotes human RBC-NOS activity, NO production and deformability through Akt kinase pathway. PLoS One 2012, 7: e45982

31. Agrawal A, McKibbin MA: Purtscher's and Purtscher-like retinopathies: a review. Surv Ophthalmol 2006, 51:129-136

32. Ramos de Carvalho JE, Schlingemann RO, Oranje M, Bemelman FJ, van Schooneveld MJ: Reversal of threatening blindness after initiation of eculizumab in Purtscher-like retinopathy secondary to atypical hemolytic uremic syndrome. Int Ophthalmol 2018, 38:399-407
33. Miguel AIM, Henriques F, Azevedo LFR, Loureiro AJR, Maberley DA: Systematic review of Purtscher's and Purtscher-like retinopathies. Eye (Lond) 2013, 27:1-13

34. Behrens-Baumann W, Scheurer G: [Purtscher disease: range of variation of clinical manifestations in 11 patients and pathogenetic considerations] German. Klin Monbl Augenheilkd 1991, 198:99-107

35. Scheurer G, Praetorius G, Damerau B, Behrens-Baumann W: Vascular occlusion of the retina: an experimental model. Graefes Arch Clin Exp Ophthalmol 1992, 230:275-280

36. Schroer H, Scheurer G, Behrens-Baumann W: Vascular occlusion of the retina: an experimental model. Graefes Arch Clin Exp Ophthalmol 1992, 230:281-285

37. Agrawal A, McKibbin M: Purtscher's retinopathy: epidemiology, clinical features and outcome. Br J Ophthalmol 2007, 91:1456-1459 